\title{
Appraisal of perspecivity of growing of decorative perennials of genus Iris L. for introduction
}

\author{
Oksana Tsandekova*, Oksana Vronskaya \\ Federal Research center for Coal and Coal Chemistry of the Russian Academy of Sciences, \\ Leningradsky av., 10, Kemerovo, 650065, Russia
}

\begin{abstract}
The results of morpho-biological observations and biochemical indicators of decorative rhizomes of the genus Iris L. of the Iridaceous family growing in the conditions of the Kuzbass Botanical Garden are represented in the article. It was established the species-specifity in the duration of vegetation period and in the level of antioxidants accumulation of in leaves of decorative redivives: I. aphylla $>I$. halophile $>I$. chrysographes $>$ I. ruthenica $>$ I. pseudacorus. According to the results of the integral appraisal, all species are perspective for use in green building. The revealed restructuring in the functioning of the antioxidant system of irises allow considering them as adaptive and protective reactions aimed at their survival and decorative qualities in the environment. The studied figures can be used as an informative parameter to assess the plants condition in the introduction.
\end{abstract}

\section{Introduction}

Irises are the decorative flowering perennials thus its abundance in accessible places of natural vegetation is significantly reduced. The comprehensive study of the irises biological features is needed to introduce the irises in the culture. In the introduction process, for the processes of adaptation of plants to new growing conditions, an ability to accumulate some secondary metabolites associated with the peculiarities of metabolic processes and the functioning of certain enzyme systems has the major importance [1 -4$]$.

Irises have some features in the adaptive strategy of forming aerial shoots. The specific conditions of the vegetative period, caused by the continental climate of Kuzbass, contribute to the identification of the physiological-biochemical features of irises, which have a long decorative and reproductive capacity for their rational use in green building. On exposure of different extreme factors the plants visually saving its decorative state undergo significant internal changes. Firstly there is an activation of the multi-level biochemical system of antioxidant protection, where a special place is occupied by low-molecular metabolites and antioxidant enzymes (ascorbic acid, tannins, peroxidase, etc.) [5,6]. Many

\footnotetext{
* Corresponding author: zandekova@bk.ru
} 
regions perform studies of irises in the terms of introduction [7 - 9], however, in the Siberian

region, they have not been studied sufficiently. Thus the identification of the matching of the growing conditions of decorative herbaceous perennials to their biological needs within the conditions of the Kuzbass is very relevant.

The aim of the work is to assess the prospectivity for growing of decorative perennials of the Iris L. genus according to phenological, morphological and biochemical features for introduction in the Kuzbass Botanical Garden.

\section{Materials and Methods}

The objects of studies were the rhizomes of the Iris L. family Iridaceae: I. aphylla L., I. chrysographes Dykes, I. halophila Pall., I. pseudacorus L., I. ruthenica Ker Gawl., growing on the territory of the Kuzbass Botanical Garden (left bank part of Kemerovo city). The soil of the experimental plot is leached chernozem with satisfactory nutrient supply. The studies were carried out in 2017-2019 in the basis of the Institute of human ecology of the Federal Research centre for coal and coal chemistry of SB RAS, Kemerovo.

By 20 species of each kind of plants in generative age state not damaged by the diseases or pests were taken for study. Phenological observations were carried performed according to the method of phenological observations in botanical gardens [10]. Appraisal of prospectively of the primary introduction of species and varieties of irises was given by the methodic of A.N. Kupriyanov [11]. The100-point grading scale was used in appraisal of winter resistance, resistance to diseases and pests, general condition of plants, ways of reproduction in culture, development of plants during the growing season. Decorativeness was evaluated according to the Method of State Crop Sorting [12]. The material for biochemical analyses was collected during the growing season (May-August). For analysis, the above-ground organs (leaves) of irises at the beginning of vegetation, in the phases of budding, flowering and fruiting were used. The content of ascorbic acid was determined by the titrimetric method using 2.6-dichlorphenodophenol [13], definition of tannin contents was made by the Leventhal-Neybower method [14], determining peroxidase activity using the method of A.N. Boyarkin [15]. Experimental data is processed statistically using computer programs StatSoft STATISTICA 8.0. for Windows and Microsoft Office Excel 2007.

\section{Results and Discussion}

Morphometric measurements of the vegetative organs of irises allowed dividing the studied irises by height to high (higher than $100 \mathrm{~cm})$ : I. pseudacorus; medium-grown (60-90 cm): $I$. halophila and I. chrysographes; and short-grown $(20-50 \mathrm{~cm})$ : I. aphylla, I. ruthenica. All irises had the lowest height of shoots in 2017 because of the hot and dry summer period. As a result of insufficient hydration during the regrowth of shoots, there was a decrease in the height of the plant's inflorescence shoots. The most favorable for the development of irises was the growing season of the year $2018-75 \%$ of species were characterized by the highest height of shoots, as there was a stable transition of temperatures through $5^{\circ} \mathrm{C}$ took place in the third decade of March and through $10^{\circ} \mathrm{C}-$ in the middle of April. The following species $I$. ruthenica, I. chrysographes, I. pseudacorus showed the highest number of points $(90-94)$ on totality of decorative signs. The studies have shown that all the species have a stable color of flower, strong peduncle and correct shape of flower. All the studied irises are original and stable within the local conditions. They may be recommended for commercial floriculture and planting in the Kuzbass local conditions. 
The main criteria of plant fitness are: the well-developed habit with good leaf coverage, the preservation of character of rhythm development within the definite limits, the passage of the full cycle of shoots development, the reproduction ability, the preservation of natural or of similar types of ontogenesis and the availability of viable self-seeding. The studied species of irises are among the easily introduced, they are good adaptable to the conditions of the botanical garden, have high productivity, abundant reproduction (seeds or vegetative), rapid change of age states.

Over the results of integral evaluation all the species are prospective for use in green building. They are winter hardy, may be slightly damaged by the diseases and pests, but well reproduce by seeds and vegetative. In studies of phenorhythms of irises growth and development it was found the active growth of plants beginning from the second decade of April till the second decade of May under the sum of positive temperatures $190-217^{\circ} \mathrm{C}$. The first buds on irises appeared in $15-25$ days after regrowth under the sum of positive temperatures $310-380^{\circ} \mathrm{C}$. Initial blossom proper to the species under examination became in 17-27 days from the beginning of budding. The beginning of flowering of I. halophila and I. ruthenica became at the end of the third decade of May - beginning of the first decade of June under the sum of positive temperatures $313-389^{\circ} \mathrm{C}$. In the first decade of June it was noted the initial blossom of $I$. aphylla under the sum of positive temperatures $412-543^{\circ} \mathrm{C}$. I. chrysographes and I. pseudacorus began its flowering in the second decade of June under the sum of positive temperatures $585-596^{\circ} \mathrm{C}$. In average the blossom duration of irises amounts to $14-21$ days. The different species of irises showed some differences in their ability to fructification, i.e.: fruits of I. pseudacorus, I. ruthenica, I. chrysographes, I. aphylla were set and matured in all years of observations. The growth season of I. aphylla, I. halophila, I. ruthenica, I. chrysographes counted to 116 days or more, I. pseudacorus showed long period (130 days or more).

Besides the morphometric and phenological features, we have conducted biochemical studies that allow us to identify the level of resistance of irises in the environment. Comparative analysis of data concerning accumulation of secondary metabolites in the leaves of herbaceous perennials revealed individual differences in the studied ornamental perennials. It was founded that the level of the ascorbic acid contents in the irises leaves in the period of vegetation increased from the beginning of vegetation till the budding (17.29 $-73.32 \mathrm{mg} / 100 \mathrm{~g})$, and reduced by the end of vegetation $(11.6-29.89 \mathrm{mg} / 100 \mathrm{~g})$. In leaves of $I$. aphylla and I. halophila it was revealed the maximum accumulation of the mentioned metabolite throughout the whole period of observations. In this period the assimilation surface of leaves developed maximally accumulating much ascorbic acid to transform it into the reproductive organs of plants. Thus, the content of ascorbic acid in the leaves of $I$. aphylla in the bud-formation period was $73.32 \mathrm{mg} / 100 \mathrm{~g}$, I. halophila $-62.27 \mathrm{mg} / 100 \mathrm{~g}$, which is by 1.2-4.2 times higher, compared to other species. Transition from the blossom stage to the fructification depends on the reduce in the content of ascorbic acid in leaves of decorative perennials. The values ranged from 11.6 to $49.4 \mathrm{mg} / 100 \mathrm{~g}$. The minimum values were noted in the leaves of I. pseudacorus and I. ruthenica (lower in $1.5-3.6$ ) relative to other plant samples.

The largest content of tannins in the irises was noted in the fructification phase $(0.89-$ $1.47 \%)$, the smallest - in the bud-formation period $(0.58-0.79 \%)$. The highest level of accumulation of the index under examination was found in the leaves of $I$. ruthenica during the vegetation period (from 0.79 to $1.47 \%$ ). In the leaves of I. aphylla the indexes varied from 0.58 to $0.89 \%$, that is lower by $17-52 \%$, than in the samples of the other species. By the end of the vegetative period, the activity of peroxidase in irises increases, which is caused by the natural aging of plants. It was noted that the enzyme activity in leaves of irises of all types during the growing ranged from 0.58 to 13.69 units of activity. In the budding phase, the minimum values of the enzyme in the samples studied $(0.58-8.12$ units 
of activity) were revealed, and the maximum values (1.03 - 13.69 units of activity) were found in the fruiting phase. Comparative analyses of decorative perennials revealed the lowest level of enzyme activity (by $6-33 \%$ ) in the leaves of I. aphylla and I. halophila compared to other species of irises. The highest activity of peroxidase during vegetation was revealed in the leaves of I. ruthenica (9.39-13.69 units of activity).

\section{Conclusion}

The complex analyses of phenological studies and biochemical indexes in irises shows the mutual dependence of these parameters which promote to its successful growth in the conditions of the Kuzbass botanical garden. According to the results of integral appraisal all the species shall be deemed as prospective for use in green building. It was established the species-specifity according to the duration of vegetation and the level of accumulation of antioxidants in leaves of decorative herbaceous perennials: I. aphylla $>$ I. halophile $>\mathrm{I}$. chrysographes $>$ I. ruthenica $>$ I. pseudacorus. The species of genus Iris L. within the period of vegetation showed some changes in the processes of metabolism. The minimum values of tannin level $(0.58-0.79 \%)$ and activity of peroxidase $(0.58-8.12$ units of activity) were revealed in the plants in bud-formation period and to the end of vegetation its contents increased. By the level of the contents of ascorbic acid it was marked the inverse relation. I. pseudacorus was characterized by the longest period of vegetation (130 days or more) and the low accumulation of secondary metabolites in leaves, relative to other species of irises. The identified rearrangements in the functioning of the antioxidant system of irises allow us to consider them as adaptive and protective reactions aimed at their survival in the environment. The studied values may be used as an informative parameter to assess the plants state in the introduction.

Work was made within the limits of the public task of the Federal research center of Coal and Coal Chemistry SB RAS over the project № 0286-2021-0010, on the basis of USI Introduction fund of the Kuzbass Botanical garden № USU 508670.

\section{References}

1. Z.V. Dolganova, Fruit and berry growing in Russia, 30 (2012)

2. L.N. Mironova, Bulletin of the Irkutsk State University of Agriculture, 44 (2011)

3. L.M Abramova, A.K. Ziganshina, Problems of botany in Southern Siberia and Mongolia, 11 (2012)

4. A.V. Kryukova, L.M. Abramova, Bulletin of the Orenburg State Pedagogical University, 2 (2016)

5. V.M. Misin, N.N. Sazhina, A.Yu. Zavyalov, Chemistry of Plant Raw Materials, 3 (2010)

6. Sh. Hu, Yu. Li, W. Wang, Ju. Jiao, M. Kou, Q. Yin, H. Xu, Ecological Indicators, 78 (2017)

7. N. B. Alekseeva, Turczaninowia, 11 (2008)

8. M. Colasante, B. Mathew, Plant Biosystems, 142 (2008)

9. B. Mitic, H. Halbritter, R. Sostaric, T. Nikolic, Plant Systematics and Evolution, 299 (2012)

10. Methodology of phenological observations in the botanical gardens of the USSR (Science, Moscow, 1975)

11. A.N. Kupriyanov, Theory and practice of plant introduction: a textbook (KREOO «Irbis», Kemerovo, 2013)

12. Methods of state variety testing of agricultural crops (Kolos, Moscow, 1968) 
13. O.A. Neverova, Workshop on biochemistry (Kemerovo Technological Institute of Food Industry, Kemerovo, 2005)

14. I.M. Korenskaya, N.P. Ivanovskaya, I.E. Izmalkova, Medicinal plants and medicinal plant raw materials containing anthracene derivatives, simple phenols, lignans, tannins (Publishing House of the Voronezh State University, Voronezh, 2007)

15. A.I. Ermakov, V.V. Arasimovich, N.P. Yarosh, Yu.V. Peruansky, G.A. Lukovnikova, M.I. Ikonnikova, Methods of biochemical research of plants (Agropromizdat, Leningrad, 1987) 